\title{
Ovarian Cystadenoma
}

National Cancer Institute

\section{Source}

National Cancer Institute. Ovarian Cystadenoma. NCI Thesaurus. Code C4060.

A benign ovarian surface epithelial-stromal tumor characterized by the presence of cystic

structures lined by serous epithelial cells, mucinous columnar epithelial cells, or endometrial-type well-differentiated cells. 